\title{
SIGNIFICANCE OF HISTORICAL AND LEGAL DISCIPLINES IN THE PROFESSIONAL TRAINING OF LAWYERS
}

\author{
Tatyana Kozhina', Alexander Petukhov ${ }^{2}$ Larisa Zinovieva $^{3}$ \\ ${ }^{1}$ Assoc. Prof. Dr., Chuvash State University, Russian Federation, tatniko@mail.ru \\ ${ }^{2}$ Assoc. Prof. Dr., Russian Presidential Academy of National Economy and Public Administration, \\ Cheboksary branch, Russian Federation, al-valerian@mail.ru \\ ${ }^{3}$ Assoc. Prof. Dr., Chuvash State University, Russian Federation, larisa-zin-cheb@mail.ru
}

\begin{abstract}
The training of professional lawyers is a multifaceted process that requires the formation of not only highly professional knowledge and skills, but also legal consciousness, legal ideology and legal culture. Professional legal culture allows a lawyer to objectively assess social reality, specific legal relations. A significant role in shaping the professional legal culture of a student belongs to historical and legal educational disciplines. By studying the history of the state and the law of their country, foreign countries, as well as the history of political and legal doctrines, students studying in the field of jurisprudence gain extensive knowledge on the evolution of the state, changing the form of the state, the form of government and the form of political regime. Strong knowledge of the processes of formation of the legal system are the fundamental basis of the professional legal consciousness of a lawyer, which determines the type of his legal culture.
\end{abstract}

Keywords: state, form of state, doctrine of state, doctrine of law, legal consciousness, legal culture.

\section{MAIN TEXT}

Reliable knowledge about the history of country's statehood and of the current state of state and law is necessary for every modern person, since "a person can be useful to his country only if he clearly sees it" (Chaadaev, 1989, p.157). Monographic studies and textbooks on the course "History of Political and Legal Doctrines" contribute to the formation of students of law schools an objective understanding of state-legal phenomena, the necessary knowledge, as well as civic qualities. Obviously, the lecturer of historical and legal disciplines must possess these qualities. "Historian, as wrote the patriarch of Russian historiography N.M. Karamzin, must rejoice and grieve with his people. He should not, led by bias, distort facts, exaggerate happiness or belittle of disaster in his account; he must first of all be honest; but he can, and must, report even the unpleasant, all the shameful in the history of his people with sadness, and he should speak with joy and enthusiasm about what bring honor, about victories, about a blossoming state of affairs. Only in this way can he become a writer of national life, whom the historian should be above all". (Karamzin, 1984, pp. 49-50)

The principle of historicism obliges to consider the phenomena of the state and law in their emergence and development, in inextricable connection with specific socio-political and economic conditions. The principle of historicism is fully consistent with the high standards of the Russian school of historians with its scientific realism (S.F. Platonov, E.V. Tarle, B.D. Grekov were its prominent representatives in the 20th century). Dissatisfaction with the results of studying the history of Soviet society, which is often demonstrated in postSoviet monographs, and especially in journalistic works, has nothing to do with the principle of historicism and scientific realism. 
The principle of educational training involves the use of the educational potential of the content of the studied basic and additional disciplines for the development of students' personalities, for the formation of positive motivation for self-education and self-development, as well as orientation to creative professional activity.

The principle of consistency in training involves the establishment of intersubject communications in the process of mastering the teachings of the state and law, as well as the formation of sustainable knowledge about the processes of change of state and legal institutions, in order to form the most complete picture of the discipline being studied.

The principle of tolerance in contemporary conditions is one of the most significant principles of educating students. In the context of a wide scientific discussion, pluralism of opinions of experts of the doctrine, it is necessary to build respect for the state and for the historical and legal experience of other countries and peoples among students. This requires solid knowledge about the historical development of the state in home country.

In the process of studying the course "History of Political and Legal Doctrines" the realization of the principle of professional orientation implies the mastery by future lawyers of professional ethics and ability to bear responsibility for the results of their professional activities. The task of the teacher is to promote the development of professional inclinations, talents, and special abilities.

The principle of spirituality in the teaching of historical and legal disciplines is manifested in the formation of stable spiritual guidelines among law students, the need for mastering the state legal experience of the previous stages in the history of the state, observance of universal human norms of humanistic morality, and the way of thinking of a Russian citizen. The principle of spirituality involves the formation of national selfawareness among students as one of the conditions for the vitality of the young generation, which ensures the connection between generations and the integrity of Russian statehood.

It is important in teaching the course "History of the Russian state and law" to fully disclose the essence of patriotism. As a rule, in the real practice of legal historical and legal education in Russia, it often comes down to military patriotic education. At the same time the peaceful aspect of patriotism, everyday citizenship, and the desire to recognize the dignity of the Fatherland remain in the shadow. At lectures and seminars on the history of the Russian state and law, attention is drawn to such features of Russian patriotism as historical continuity, peacemaking, spiritual fulfillment, openness to dialogue with other legal systems. For example, when studying the period of the formation of the Russian centralized state, primary attention is paid to the content of the theory "Moscow is the Third Rome" and the analysis of the Code of Law (1497) (Sudebnik). Of particular interest to students is the period of development and adoption of the Code of Law (1649) (Sobornoye Ulozheniye), the sources of which were both the norms of Rus' Law (Russkaya Pravda), Codes of Law (1497 and 1550), and the Lithuanian Statutes.

Yuri Krizhanich (Juraj Križanić) belongs to the large group of Russian thinkers of the second half of the 17th century, educated natives from Byzantium and Eastern and Western Europe. As a rule, these people formed in different national historical conditions than in Russia. Scientific discussions are being held on the nature of the influence of these thinkers on the development of Russian political thought and even on the legitimacy of considering them as representatives of Russian political thought.

Yuri Krizhanich was born in Croatia, which was under Turkish rule. All his life he was an ardent Slavic patriot, he considered Russians the dearest people to him. The dream of uniting all the Slavs into a single state under the leadership of Russia brought him to Moscow.

Naturally, the pan-Slavic ideas of Yuri Krizhanich could not but arouse sympathy for him at the royal court. At the same time, his Catholic faith, his conviction that the Slavs could unite only on the basis of the Uniate Church, contradicted the claims of Russian Orthodoxy to the monopoly possession of Christian truth. Obviously, this was the reason that in 1661, after a two-year stay in Moscow he was exiled to Tobolsk based on slanderous denunciation, with specious motivation: "to be there for the tsar's affairs". His exile lasted 15 years. The main works of Y. Krizhanich were written in the exile: "On Politics", "On Divine Providence", "An Interpretation of Historical Prophesies". In 1626 Krizhanich was released from exile and tried to leave Russia as soon as possible.

The works of Krizhanich first began to be published in the 1820s. His contemporaries claim that the works of Krizhanich were known to a considerable circle of people, were stored in the tsar's library, and the copies went to the hands of private individuals. By their content and form, the works of Krizhanich belong to purely theoretical works, which is unusual for the vast majority of works on which we study Russian state-legal thought until the 17 th century.

Krizhanich believed that "politics, or royal wisdom, is the noblest... of all worldly sciences, and of all sciences 
it is the most decent to kings and their advisers" (Krizhanich, 1965, p. 221). It is not difficult to identify in Krijanich the supporter of Plato, who considered politics to be a science that completes the pyramid of knowledge, since it is designed to ensure the benefit of human life. The subject of political science, according to Krizhanich, is not power and power relations, but the arrangement of a state in which a person would be happy. Krizhanich identifies two types of means of society's building: political and educational. The second is an instrument in the hands of a politician. But politics itself is understood as the science of the arrangement of the state, a universal mean of achieving social welfare.

Based on the ancient tradition dating back to Plato and Aristotle, Krizhanich divides the states into right and wrong. The thinker considers "perfect autocracy" (monarchy), boyar rule (aristocracy), and posad rule (republic) as correct forms of state's government. Accordingly, the wrong forms of government are tyranny, "young rule" (oligarchy) and "general rule" (anarchy).

The best form of the state, from the point of view of Krizhanich, is "autocracy" (absolute monarchy), which ensures observance of universal justice, preservation of peace and harmony among the people, and guarantees the safety of society. Krizhanich is a supporter of absolutism. At the head of state, he sees a monarch-philosopher, who should have the strength and wisdom, as well as have the love of the people. The state can have only one goal - achieving common benefits for all people, the state can fulfill its role only by managing and controlling all aspects of society. It determines, taking into account the natural conditions, where and which crafts to develop, takes care of the rational use of natural resources and land. Confidence that the sovereign's power is able to make people happy and solve all problems sounds in his appeal to Tsar Alexey Mikhailovich: "You are a king, holding in your hands the miraculous rod of Moses, with which you can create marvelous miracles; in your hands is complete autocracy". But the absolute fullness of the power of the monarch does not mean his arbitrariness in governance. The monarch establishes laws that are binding not only on subjects, but also on the legislator. "Laws not only fulfill a regulatory function. They contain the essence of justice. Good laws do not contradict natural human rights, they take into account the customs of the people. Laws should not be cruel. Their cruelty is the cause of social instability. Where laws are cruel, the subjects themselves crave a change in government and often change if they can. What are the laws such is the order of things in the state, so predatory laws always and everywhere cause disorder." (Krizhanich, 1965, p. 381).

Education was considered the strongest means of arranging society. The tsar should pursue a focused educational policy. We are talking about education, understood in the broad sense of the word, i.e. about the development of science, printing, education of the population. He attached particular importance to the dissemination of literacy among the people. He even advised resorting to violence against persons who avoid learning. For example, Krizhanich proposes to close the shop of an illiterate merchant for a time until he learns arithmetic. He proposed do not allow noblemen and merchants to marry without being educated.

Being a supporter of a centralized state governed by an autocratic tsar, Krizhanich simultaneously opposes strict centralized regulation that excludes all free activity. He is convinced that the economic well-being of the country, the development of industry, agriculture, crafts is impossible without the initiative, independence and enterprise of all citizens.

Krizhanich proposes to consolidate the system of "slobodin" (freedoms) by law, which means the social, economic and political rights of individuals and estates. In his opinion, cities should be granted the right to self-government. His proposition is to form bodies of city self-government, first part of whose representatives are appointed by the tsar, and the second part should be elected. The right to form self-government bodies must also be granted to the third estate. For example, the merchants choose their elders and their court. Craftsmen unite in corporations, all those involved in industry can apply to the government for their needs. And the tsar must give freedom and the right for free labor to the peasants. In the "slobodin" Krizhanich saw a legal instrument of protection against the arbitrariness of a state person, who is not stopped by abuses or punishment.

In his works, Krizhanich paid great attention to nurturing the political consciousness of Russian society through the formation of patriotism, a sense of national dignity and pride for Russian history. At the same time, he is merciless in criticizing Russian reality, describing it, he does not spare the black paint. "The Russian people are stupid, oblique, inept, lazy, non-initiative, do everything only under duress, they are unclean, wears untidy clothes, walks with unkempt heads and beards, drinks a lot." Krizhanich, describing the life, customs and ideas of Russians, constantly compares Russian reality with Western Europe's one, which allows him to strengthen the imagery of criticism. But already at that time, he saw the negative consequences of Westernizing of the Russian society.

Krizhanich was a typical representative of the patriotic moods of Westerners, who saw in European 
enlightenment and education, science, technology and culture the only means of creating an advanced and powerful state. However, the addiction to the Western, in his opinion, took the form of "chuzhebesie", i.e. people's servile attitude to foreign things, accompanied by a contemptuous attitude to everything Russian. Russians worship not only foreign things, but also foreigners, which is why "chuzhevladstvo" (foreign domination) has arisen. Krizhanich laments that foreigners fool Russians, call us pigs and dogs, sit on our shoulders and ride us".

"Chuzhebesie" leads to the fact that instead of a sense of national dignity and noble pride, society suffers from excessive conceit that does not allow it to see its shortcomings. It is easy to see that much of what Krizhanich noticed in the attitude of Russians to the West and vice-versus remains topical today.

Krizhanich consistently upheld the historical conception that the peoples themselves are the creators of the history of the Slavs in general and the Russians in particular. He is one of the few thinkers who reject the Varangian theory of the origin of the Russian people and state. He considered the legend of the invitation of Rurik, Sineus and Truvor as a lie from beginning to end. "In the story, first of all, it was a lie, as if the Novgorodians sent to the Vikings to ask the prince, because the Novgorodians could not be so stupid as to do this ... Why did they divide their power? Novgorodians could expect strife and separation rather than consent, and there can be no people in the world so stupid as not to understand this." (Krizhanich, 1965, p. 624).

Krizhanich not without reason sees in the Varangian version of the origin of the Russian state the negative consequences of all the same Westernism. Such a political theory, which, moreover, does not rely on actually proven historical facts, cannot contribute to the formation of Russian feelings of patriotism and selfconfidence. In his political teaching, Krizhanich paid much attention to the problems of international relations and Russia's foreign policy. Since wars were often waged on the European continent, the main issues in the theory of international relations were issues of war and peace.

Krizhanich believed that the goal of foreign policy is to maintain peace between states. The sovereign must take care of peace and quiet for his people by concluding peace, peace treaties with peoples like themselves, i.e. close in religion, culture and lifestyle.

Understanding that war from the life of society cannot be completely eliminated, Krizhanich would like to alleviate the suffering of people during the war. This can be achieved by establishing the rules and moral standards of warfare. It should not be started without good reason. If it was not possible to avoid military operations, then they should be announced through a messenger and fight according to the established rules. "Firstly, to fight only for a just cause, secondly, to spare innocent people, thirdly, to protect churches and girls, fourthly, to spare the blood of their soldiers, fifthly, not to rejoice and not to boast about defeating the enemy, sixthly, to think that all victory is from God". (Krizhanich, 1965, p. 654)

The highest goal of Russian politics, Krizhanich considered the unification of the Slavs under the leadership of Moscow. Criticizing the theory "Moscow is the Third Rome", he adhered to the Pan-Slavic messianism. World history is presented to him in the form of a change of peoples, taking turns accepting and preserving world science and art and developing wisdom further. It is the turn of the Slavs. The fulfillment of this role requires a union, which should be carried out on three grounds. The first ground is a single Slavic language, the creation of which should be worked hard. Krizhanich himself developed a grammar and compiled a dictionary of the Slavic language. The second ground is a single religion, which, in his opinion, could be Uniate (a kind of Catholicism). And the third ground is a single political center.

Political and legal works of Krizhanich, like the works of his contemporary, Russian statesman and thinker Ordin-Nashchokin, ideologically prepared the reforms of Peter I. Despite the significant differences in the formation of both thinkers (Ordin-Nashchokin, who was born and formed in Russia, Krizhanich, who was a foreigner, a Catholic), they are united by a common attitude towards the West and Russia, general ideas about the type of Russian statehood, about the content and directions of state policy in the field of economics, social and cultural development of the Russian society. The commonality of the political views of thinkers is explained by one thing - Russia objectively entered a new historical era, the era of absolutism, which was also prepared theoretically.

Historical and legal science today performs several functions. First of all, this is a worldview function. The transition of society to a new quality, practically the emergence of a new state, with a new political and legal system, with new paradigms and guidelines, the rejection of the previous system and the old paradigm of explanation of state and legal institutions created a kind of worldview vacuum. The scientific and university community is forming a new methodology, a new approach to state-legal phenomena. 


\section{REFERENCE LIST}

Chaadaev, P. (1989). Articles and Letters. Moscow.

Karamzin, N.M. (1984). Sochineniya. Leningrad. Vol. 2.

Klyuchevsky, V.O. (1988). Works: In 9 vol. Moscow.

Krizhanich, Y. (1965). Politics. Moscow.

Machin, I.F. (2016). History of Political and Legal Doctrines. Moscow.

Vlasov, V.I. (2016). History of Political and Legal Doctrines. Moscow.

Rubanik, V.E. (2015). The History of the State and Law of Russia in 2 vol. Moscow. 